\title{
Delayed-Type Hypersensitivity in Sheep Induced by Synthetic Peptides of Bovine Leukemia Virus Encapsulated in Mannan-Coated Liposome
}

\author{
Kosuke OKADA $^{1)}$, Kai SONODA ${ }^{1)}$, Masato KOYAMA ${ }^{1)}$, Shanai YIN ${ }^{1)}$, Manabu IKEDA ${ }^{1)}$, Masanobu GORYO ${ }^{1)}$, \\ Sau Leok $\mathrm{CHEN}^{1)}$, Hidenori KABEYA ${ }^{2)}$, Kazue OHISHI ${ }^{1)}$ and Misao ONUMA ${ }^{2)}$ \\ ${ }^{1)}$ Department of Veterinary Pathology, Faculty of Agriculture, Iwate University, 3-18-8 Ueda, Morioka, Iwate 020-8550 and \\ ${ }^{2)}$ Department of Epizootiology, Faculty of Veterinary Medicine, Hokkaido University, N18 W9 Kita-ku, Sapporo 060-0818, Japan
}

(Received 25 July 2002/Accepted 20 December 2002)

ABSTRACT. Four sheep were immunized with synthesized peptides, derived from bovine leukemia virus (BLV) envelope glycoprotein, encapsulated in mannan coated liposomes as adjuvant. On the seventh day after the immunization, the sheep were intradermally challenged with BLV antigen, or synthesized peptides. The areas challenged with antigen were increased skin thickness and biopsied sequentially for immunohistological examinations. Strong delayed-type hypersensitivity was induced in sheep immunized and challenged with peptides encapsulated in mannan-coated liposomes. The major phenotype of the infiltrating lymphocytes was $\mathrm{CD} 5{ }^{+}$. The ratio of CD4 to $\mathrm{CD} 8^{+}$cells was about $1: 1$.

KEY WORDS: bovine leukemia virus, delayed-type hypersensitivity, mannan-coated liposome.

J. Vet. Med. Sci. 65(4): 515-518, 2003

Bovine leukemia virus (BLV) is associated with the development of persistent lymphocytosis and B cell lymphoma in cattle. Generally, retrovirus infection leads to both humoral and cell-mediated immunity. Previously, it was reported that recombinant vaccinia virus (rVV) expressing BLV Env suppressed BLV replication in naive and carrier sheep [14]. That rVV could not induce detectable levels of anti-BLV antibodies but induced strong cell-mediated immunity as assessed by delayed-type hypersensitivity (DTH) and lymphocyte proliferative responses, suggested that the rVV rendered its suppressive effect on BLV replication primarily via the augmentation of cell-mediated immunity $[12,14,15]$. Gatei et al. [7] also carried out a vaccine trial in sheep using BLV env -rVV, and reported the correlation of protection with $\mathrm{CD} 4^{+} \mathrm{T}$-cell proliferative responses. Thus, cell-mediated immune responses are believed to play an important role in controlling BLV replication.

Subunit vaccines that use a pure, defined soluble protein or peptide are thought to be safer than live, infectious expression vectors, but require the use of adjuvant due to their limited immunogenicity. Among novel antigen delivering formulations developed to overcome this problem, mannan-coated liposomes incorporating a recombinant protein were shown to induce a $\mathrm{CD}^{+}$cytotoxic $\mathrm{T}$ lymphocyte (CTL) and DTH responses $[11,16]$.

The peptide of BLV envelope glycoprotein gp51 has been analyzed as an epitope which induces cell-mediated immunity $[2,7,10]$. In the BLV envelope glycoprotein gp51, a peptide of 98-117 amino acids contains a Th epitope [2] and that of 121-140 amino acids contains a CTL epitope [6]. Recently, BLV Env-specific Th1 type immunity was induced in mice by vaccination with short synthesized 98117 peptide encapsulated with mannan coated liposome [13]. Furthermore, the 121-140 peptide eliminated BLV infected cells in carrier sheep [8]. Therefore, we used syn- thesized peptides of 98-117 and 121-140 amino acids of BLV envelope glycoprotein gp51 encapsulated in mannancoated liposomes, as a vaccine. The purpose of the present study was to examine whether DTH can be induced by the immunization of this vaccine and to determine the phenotype of lymphocytes in skin lesions challenged with antigens.

Ten mixed breed sheep under 6 months of age (Nos. 1$10)$ were used. All sheep had been previously confirmed as BLV negative by agar gel immunodiffusion tests. The BLV virions and envelope glycoprotein antigens were supplied by Prof. Koyama of Kitazato University, Japan.

The sheep were divided into five groups, and immunized intradermally on the left side of the neck in each sheep as follows: group A (Nos. 1, 2), no treatment; group B (Nos. 3, $4)$, inoculated with only mannan-coated liposome; group C (Nos. 5, 6), inoculated with synthesized peptides (98-117, 121-140, $100 \mathrm{mg} / \mathrm{sheep)} \mathrm{encapsulating} \mathrm{with} \mathrm{liposome;}$ group D (Nos. 7, 8), inoculated with a small dose of synthesized peptides (98-117, 121-140, $100 \mathrm{mg} / \mathrm{sheep})$ encapsulated in mannan-coated liposome; group E (Nos. 9, 10), inoculated with a large dose of synthesized peptides (98$117,121-140,200 \mathrm{mg} / \mathrm{sheep})$ encapsulated in mannancoated liposome.

On the seventh day after immunization, these sheep were injected intracutaneously on the left side of the lateral region in each sheep with either BLV (2 unit/100 ml) or synthesized peptide of 98-117 or 121-140 amino acids (each 100 $\mathrm{mg} / 100 \mathrm{ml}$ ) of BLV gp51 as an antigen. Keyhole limpet hemocyanin (KLH, $0.5 \mathrm{mg} / 100 \mathrm{ml}$ ) was used as a control.

The areas challenged with antigens on the left side of the lateral region in each sheep were biopsied at 3, 24, 48 and 72 hr post-challenge, respectively for immunohistological examinations.

Tissues were either fixed in $10 \%$ formalin and embedded 
Table 1. Immunohistologic findings on infiltration by lymphocytes in sheep Nos. 6, 8, 9 and $10^{\text {b) }}$

\begin{tabular}{|c|c|c|c|c|c|c|c|c|c|}
\hline \multirow[t]{2}{*}{ Group $^{\text {a) }}$} & \multirow[t]{2}{*}{ Sheep No. } & \multirow[t]{2}{*}{ Antigen } & \multirow{2}{*}{$\begin{array}{c}\text { Time after } \\
\text { challenge (hr) }\end{array}$} & \multicolumn{6}{|c|}{ Severity of lesion and infiltration by cells with the following marker } \\
\hline & & & & CD5 & CD4 & CD8 & WC1 & $\mathrm{MHC} \mathrm{II}^{\mathrm{c})}$ & B \\
\hline \multirow[t]{3}{*}{$\mathrm{C}$} & 6 & $121-140$ & 24 & - & - & - & - & - & - \\
\hline & & & 48 & + & - & - & - & ++ & - \\
\hline & & & 72 & - & - & - & - & ++ & - \\
\hline \multirow[t]{6}{*}{$\mathrm{D}$} & 8 & BLV & 24 & - & - & - & - & - & - \\
\hline & & & 48 & - & - & - & - & - & - \\
\hline & & & 72 & + & \pm & \pm & - & + & - \\
\hline & & 98-117 & 24 & - & - & - & - & - & - \\
\hline & & & 48 & + & \pm & \pm & - & + & - \\
\hline & & & 72 & - & - & - & - & - & - \\
\hline \multirow[t]{12}{*}{ E } & 9 & BLV & 24 & ++ & + & \pm & + & - & - \\
\hline & & & 48 & ++ & ++ & ++ & - & ++ & - \\
\hline & & & 72 & ++ & \pm & + & - & + & - \\
\hline & & $98-117$ & 24 & ++ & \pm & + & - & ++ & - \\
\hline & & & 48 & ++ & ++ & \pm & - & ++ & - \\
\hline & & & 72 & ++ & \pm & \pm & - & + & - \\
\hline & 10 & BLV & 24 & ++ & + & ++ & ++ & + & - \\
\hline & & & 48 & ++ & ++ & \pm & + & ++ & - \\
\hline & & & 72 & ++ & - & - & - & ++ & - \\
\hline & & 98-117 & 24 & ++ & + & \pm & - & ++ & - \\
\hline & & & 48 & ++ & + & + & - & ++ & - \\
\hline & & & 72 & ++ & \pm & + & - & ++ & - \\
\hline
\end{tabular}

-: non, \pm : slight (under 30), +: moderate (30 to 50), ++: marked (more than 50 cells were cousnted in one field at a magnification of $\times 400$ under a light microscope). a) Group C: inoculated with a small dose of synthesized peptides in liposome. D: inoculated with a small dose of synthesized peptides in mannan-coated liposome. E: inoculated wiht a large dose of synthesized peptides in mannan-coated liposome. b) Data of sheep Nos. 1-5, 7 were not shown because their infiltration of lymphocytes was slight. c) $\mathrm{MHC}$ II=major histocompatibility complex class II.

in paraffin for histological examination, or embedded in optimal cutting temperature compound by rapid freezing in liquid nitrogen and stored at $-80^{\circ} \mathrm{C}$. Frozen sections of skin biopsies were examined by the avidin biotin peroxidase complex (ABC) method, using a Vectastain ABC kit (Vector Laboratories, Burlingame, CA, U.S.A.).

Selected monoclonal antibodies specific to sheep lymphocyte and granulocyte/ monocyte subsets were used as the primary antibodies: ST-1 (anti-OvCD5; all T cell, [5]), 17D13 (anti-OvCD4; helper/inducer T cell, [9]), CACT80C (anti-OvCD8; cytotoxic/suppressor T cell, [3]), BAQ4A (WC1 cells; $\gamma / \delta \mathrm{T}$ cell receptor ${ }^{+}$, [3]), H42A (anti-major histocompatibility complex [MHC] class II, [4]) and E-53 (anti-B cells, [5]). Anti-ColiS69A and BAHO16A MoAbs (Dr. W.C. Davis, Washington State University) were used as negative controls for isotype $\operatorname{IgG}_{1}$ and $\operatorname{IgM}$, respectively. Numbers of cells were counted inside the photographic field at a magnification of $\times 400$ under a light microscope. Five different fields were examined in each skin lesion at each time point.

No DTH response was observed in the sheep challenged with KLH and sheep from groups $\mathrm{A}$ and $\mathrm{B}$, indicating that the responses were BLV antigen specific. In sheep groups C (No. 6), D (No. 8), and E (Nos. 9, 10), moderate to marked infiltration by lymphocytes was observed in the dermis at 24 to $72 \mathrm{hr}$ post-challenge with BLV or synthesized peptides.
Stronger DTH responses, evaluated by thickness of challenged skin sites and immunohistological lymphocyte infiltration, were observed in the sheep inoculated with peptides in mannan-coated liposomes (group D) than those inoculated with peptides in mannan-free liposome (group C).

The immunohistologic findings on infiltration by lymphocytes observed in sheep Nos. 6, 8, 9 and 10 are shown in Table 1 . The phenotype of most of the infiltrating lymphocytes was $\mathrm{CD}^{+}$. The ratio of $\mathrm{CD}^{+}$to $\mathrm{CD} 8^{+}$cells was about 1:1 (Fig. 1) at each time point.

MHC class II positive cells were found in group C (No. 6) and group E (Nos. 9, 10). The number of these cells was moderate at 24 and $72 \mathrm{hr}$ post-challenge but increased markedly at $48 \mathrm{hr}$ post-challenge by BLV or peptide. WC1 cells were observed in sheep No. 10, but the number of WC1 cells did not change in areas of DTH response.

This DTH response in this study was moderate compared to that in sheep induced by rVV [14]. The difference might be due to the use of subunit vaccine instead of live vaccine, or of partial peptides rather than whole protein of $e n v$ as antigen.

In the present study, the phenotype of the major infiltrating lymphocytes in sheep inoculated with synthetic peptides and challenged with either BLV or the peptides was $\mathrm{CD}^{+}$. The ratio of infiltrating $\mathrm{CD} 4^{+} / \mathrm{CD}^{+}$cells was about $1: 1$. This ratio was also different from that reported previously 

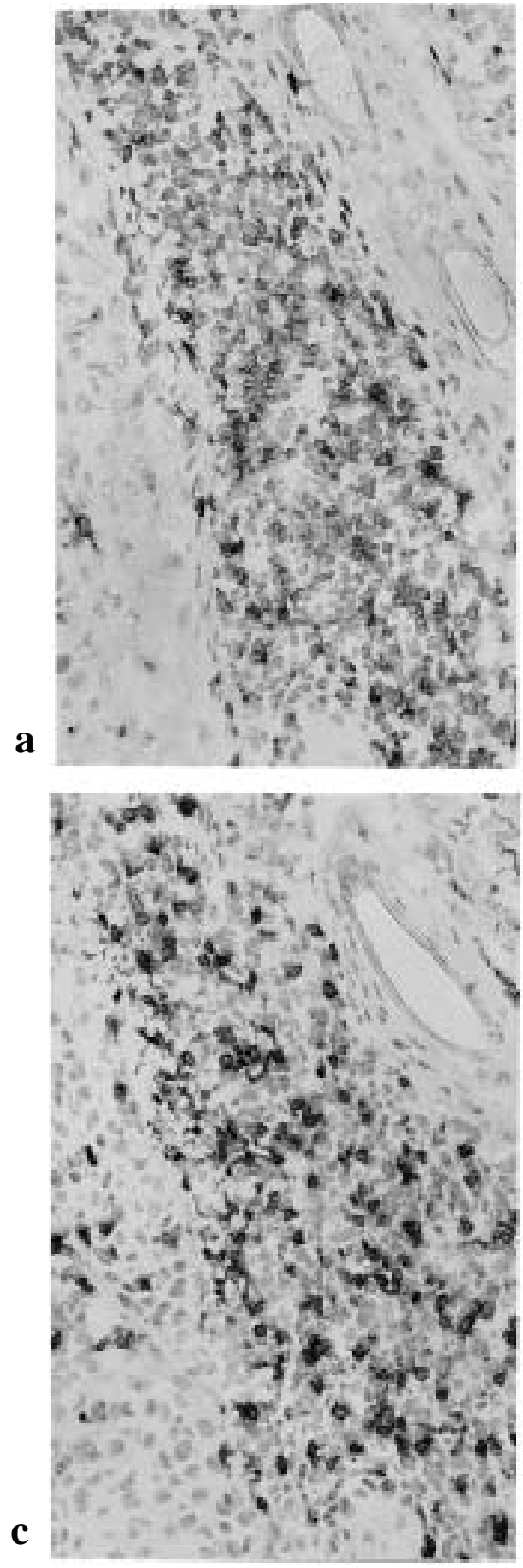

(i.e. 1: 2) for sheep immunized with rVV [12]. This difference might be due to the difference of antigenic nature.

Infiltration by MHC class $\mathrm{II}^{+}$cells reached a maximum at $48 \mathrm{hr}$ post-challenge. Most of the cells infiltrating MHC class $\mathrm{II}^{+}$cells in the present study appear to be activated $\mathrm{T}$ cells because positive cells were observed in areas where few macrophages were detected. MHC class $\mathrm{II}^{+}$cells may specifically react to synthesized peptide vaccines because

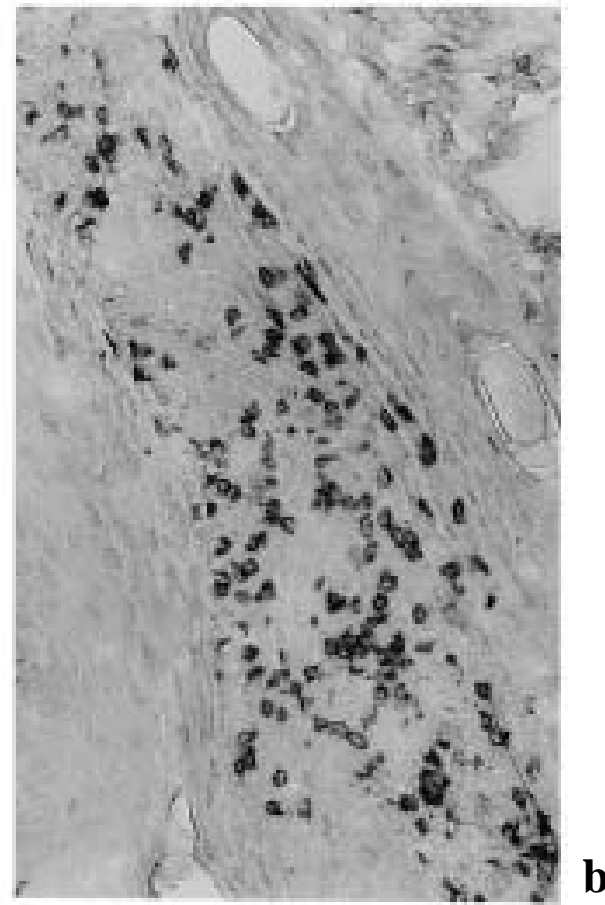

b

Fig. 1. Immunohistology of skin lesion; Sheep No.8, group D (a small dose of mannan-coated liposome encapsulating synthesized peptides), $48 \mathrm{hr}$ post-challenged with peptide $98-117$ (ABC method, $\times 200$ ). (a) Many CD5 positive cells are scattered in the dermis (ST-1). (b) CD4 positive cells are scattered in the dermis (17D-13). (c) CD8 positive cells are scattered in the dermis (CACT80C).

these cells were not observed in areas where KLH was injected as antigen.

WC1 cells may be associated with DTH response, because Th1 cells, as a subset of CD4 cells, stimulate WC1 cells [1]. However the number of WC1 cells did not change in areas of DTH response indicating that WC1 cells were not involved in the response of this experiment. The reason was unknown. 
The present results indicated that the immunization of synthesized peptides, encapsulated in mannan-coated liposomes as adjuvant can induce DTH responses in sheep and demonstrated infiltration by antigen specific $\mathrm{CD}^{+}$and $\mathrm{CD}^{+} \mathrm{T}$ cells.

ACKNOWLEDGMENT. This study was supported in part by a Special Coordination Fund of the Science and Technology Agency of the Japanese Government.

\section{REFERENCES}

1. Brown, W. C., Estes, D. M. and Rice-Ficht, A. C. 1996. J. Interferon Cytokine Res. 16: 647-648.

2. Callebaut, I., Vone'che, V., Mager, A., Fumie're, O., Krchnak, V., Merza, M., Zavada, J., Mammerickx, M., Burny, A. and Portetelle, D. 1993. J. Virol. 67: 5321-5327.

3. Davis, W. C., Hamilton, M. J., Park, Y., Larsen, R. A., Wyatt C. R. and Okada, K. 1990. pp. 47-70. In: Monographs in Animal Immunology 1, Bar-Lab, Inc. Blacksburg, Virginia.

4. Davis, W. C., Murusic, S., Lewin, H. A., Splitter, G. A., Perryman, L. E., McGuire, T. C. and Gorham, J. R. 1987. Vet. Immunol. Immunopathol. 15: 337-376.

5. Ezaki, T., Parisot, R., Dudler, L., Beya, M. F., Miyasaka, M. and Trnka, Z. 1985. pp. 88-109. In: Immunology of Sheep, F. Hoffmann-La Roche and Co., Basel.

6. Gatei, M. H., Good, M. F., Daniel, R. C. W. and Lavin, M. F. 1993a. J. Virol. 67: 1796-1802.
7. Gatei, M. H., Naif, H. M., Kumar, S., Boyle, D. B., Daniel, R. C. W., Good, M. F. and Lavin, M. F. 1993b. J. Virol. 67: 18031810.

8. Kabeya, H., Ohashi, K., Ohishi, K., Sugimoto, C., Amanuma, H. and Onuma, M. 1996. Vaccine 14: 1118-1122.

9. Mackay, C. R., Hein W. R., Brown, M. H. and Matzinger, P. 1988. Eur. J. Immunol. 18: 1681-1688.

10. Mamoun, R. Z., Morisson, M., Rebeyrotte, N., Busetta, B., Couez, D., Kettmann, R., Hospital, M. and Guillemain, B. 1990. J. Virol. 64: 4180-4188.

11. Noguchi, Y., Noguchi, T., Sato, T., Yokoo, Y., Itoh, S., Yoshida, M., Yoshiki, T., Akiyoshi, K., Sunamoto, J., Nakayama, E. and Shiku, H. 1991. J. Immunol. 146: 35993603.

12. Okada, K., Ikeyama, S., Ohishi, K., Suzuki, H., Sugimoto, M., Numakunai, S., Chiba, T., Murakami, K., Davis, W. C., Ohshima, K. and Ikawa, Y. 1993. Vet. Pathol. 30: 104-110.

13. Ohishi, K., Kabeya, H., Amanuma, H. and Onuma, M. 1996. Vaccine 14: 1143-1148.

14. Ohishi, K., Suzuki, H., Yamamoto, T., Maruyama, T., Miki, K., Ikawa, Y., Numakunai, S., Okada, K., Ohshima, K. and Sugimoto, M. 1991. J. Gen. Virol. 72: 1887-1892.

15. Ohishi, K., Suzuki, H., Yasutomi, Y., Onuma, M., Okada, K., Numakunai, S., Ohshima, K., Ikawa, Y. and Sugimoto, M. 1992. Microbiol. Immunol. 36: 1317-1323.

16. Sugimoto, M., Ohishi, K., Fukasawa, M., Shikata, K., Kawai, H., Itakura, H., Hatanaka, M., Sakakibara, R., Ishiguro, M., Nakata, M. and Mizuochi, T. 1995. FEBS Letters 363: 53-56. 